\title{
Studies on Diversity of Spider Fauna in Ahmednagar District, Maharashtra State, India
}

\section{A. R. Gawali ${ }^{1}$, G. S. Pande and *R.D. Gawali ${ }^{1}$}

Department of Zoology,

B. P. H. E. Society's Ahmednagar College, AHMEDNAGAR-414001 (M.S.) INDIA,

${ }^{1}$ Department of Zoology,

K.J. Somaiya College of Arts, Commerce and Science,

KOPARGAON-423601 (M.S.) INDIA

*Corresponding Author

Received : 25.08.2020; Accepted : 28.09.2020

E-mail: rdgawali@gmail.com

\begin{abstract}
The order Aranae of class Arachnida has a special value in the studies of ecology as it serves as a biological indicator. The main objective of the present study was to findout the diversity and characteristics of spiders from Ahmednagar district. The study on diversity of spider was conducted from various collection sites such as Kopargaon, Madhi Bk, Kumbhari (Godavari River area), Faria bag, Pimpalgaon Malvi, Dongargan, Mahatma Phule Krishi Vidyapeeth, Rahuri and Kolhar. The 108-specimen spiders were collected from various sites. The spider specimen collected were photographed, observed, identified and classified with the help of Zoological Survey of India, Pune. Out of 60 specimens identified, belong to 09 families and 18 genera.

Figures : $27 \quad$ References : 34

Tables : 03

KEY WORDS : Biodiversity, Biological indicator, Ecology, Godavari River, Spider.
\end{abstract}

\section{Introduction}

India has plenty of flora and fauna and has mega diversity in the world. The knowledge regarding the diversity, distribution and abundance of spider in India is scattered variably. Spiders are the most diverse group of organism. Spider acts as bio-control agent ${ }^{3}$. Spiders maintain and regulate the terrestrial arthropod population as they form important predators ${ }^{5,25}$. Spiders are ample in number and are ecologically important in almost all terrestrial habitats. There are about 37,000 identified spider species which is a small number of their total diversity ${ }^{1}$.

Spiders are found to be predators in several ecosystems. Spiders also form an important food source for bird, lizard, wasps and other animals ${ }^{13}$. Spider silk is important to some birds for preparation of their nests, Out of 42, 24 families of passerine birds and nearly all species of humming birds depend on spider's silk and caterpillars to build their nests ${ }^{11,27}$. Spiders are found in terrestrial ecosystem and also few species occur in freshwater and marine water habitats ${ }^{6}$.
To identify spiders on the basis of morphological features is very difficult task. Problems in arachnid identification are also due to moulting in many species which continue to grow as adults, leading into gross size differences, for example some Nephilia males are double the length of others ${ }^{4}$. By considering the importance of spiders in the natural reduction of many insect pests and as bioindicators, immediate efforts are essential to understand spider's diversity. The present knowledge of spiders of Western Ghat refers to the work $^{2,8,9,12,14,15,23,24,28}$ tried to collect data for documentation of diversity of spider's fauna in Western Ghat.

The 42 species of spiders were under 20 genera and 14 families at Sawanga-Vithoba Lake region, District Amaravati, State of Maharashtra, India ${ }^{34}$.

The present study was undertaken to investigate the diversity of spiders. We hope that the results obtained from this study will be helpful in updating faunal data of the Ahmednagar region and will inspire future research workers. 


\section{Material and Methods}

Study Area: Study area of this work was District Ahmednagar which is located in Maharashtra state of India. $\left(19.4555^{\circ} \mathrm{N}, 74.4057^{\circ} \mathrm{E}\right)$. The study on diversity of spider was conducted from various collection sites such as Kopargaon, Madhi BK, Kumbhari (Godavari River), Faria bag, Pimpalgaon Malvi, Dongargan, Mahatma Phule Krishi Vidyapeeth, Rahuri, Kolhar as shown in Table-1. The 108-Specimen spiders were collected from various sites during July 2018 to August 2018.

Collection site was surrounded by some urban area, hilly area and most agricultural fields. Spider specimens were collected from residential area, forest plantation, crops and agriculture fields from various localities of Ahmednagar district.

Following methods were used for the collection: (1) Hand picking and (2) Sweep Netting using insect collection Net. The specimens were preserved in $70 \%$ alcohol, labeled and sent to Z.S.I. (Zoological Survey of India) for identification by the Expert in Spider Taxonomy. Some species of spiders were observed and identified by using the reference books ${ }^{29,30,31}$. Before preservation, all specimens were photographed by MI Mobile Camera, Model No: Redmi 4.

Total 108 Spider specimens were collected from different localities in study area and identified with assistance of experts from Zoological Survey of India, Pune (Ref. File No. 6-1/Tech./ 2019-20/ 347, dated 01.04.2019) together with keys ${ }^{31}$.

\section{Results}

The list of spider species is presented below (Table-2). Out of 60 specimens, 27 Species represent 09 families and 18 genera. The Araneidae is the most represented family with 12 species followed by Salticidae

TABLE-1 : Locations of Selected Collection Sites for Survey of Spiders

\begin{tabular}{|c|c|c|c|}
\hline & Locality/Collection Site & Geographical Location & Habitat type \\
\hline 1) & Residential area (House), Kopargaon & $\begin{array}{l}\text { N 1953'35.1" } \\
\text { E 0741'ㄱ' } 26.4^{\prime \prime}\end{array}$ & $\begin{array}{l}\text { Collected from } \\
\text { residential area }\end{array}$ \\
\hline 2) & K. J. S. College Campus, Kopargaon & $\begin{array}{l}\text { N 1952'27.7" } \\
\text { E 074² } 28^{\prime} 57.7^{\prime \prime}\end{array}$ & Botanical garden \\
\hline 3) & Madhi B.K., Kopargaon & 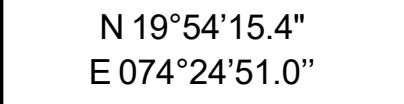 & Agriculture field \\
\hline 4) & Faria Bag, Ahmednagar & $\begin{array}{l}\text { N 1953'35.1" } \\
\text { E 0741'26.4" }\end{array}$ & Forest \\
\hline 5) & Pimpalgaon Malvi, Ahmednagar & 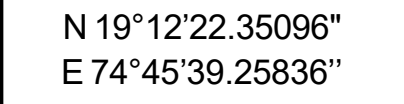 & Agriculture field \\
\hline 6) & Dongargan, Ahmednagar & $\begin{array}{l}\text { N 19¹5'1.28556" } \\
\text { E 744ㄴ'28.8096" }\end{array}$ & Mountain rock \\
\hline 7) & Godavari River, Kumbhari, Tal- Kopargaon & $\begin{array}{l}\text { N 1954'15.4" } \\
\text { E 074²4'51.0" }\end{array}$ & River side- wet area \\
\hline 8) & M.P. Krishi Vidyapeeth, Rahuri, Ahmednagar. & 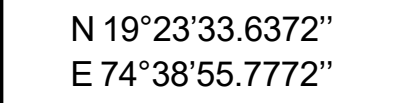 & Agriculture field \\
\hline 9) & Kolhar, Tal- Rahata, Ahmednagar. & $\begin{array}{l}N 19.2045^{\circ} \\
E 74.8887^{\circ}\end{array}$ & Neem Tree \\
\hline
\end{tabular}


TABLE-2 List of Spider Species Reported from Present Study

\begin{tabular}{|c|c|c|}
\hline Name of Family & & Zoological Name \\
\hline Araneidae & $\begin{array}{l}1 . \\
2 . \\
3 . \\
4 . \\
5 . \\
6 . \\
7 . \\
8 . \\
9 . \\
10 . \\
11 . \\
12 .\end{array}$ & $\begin{array}{l}\text { Araneus sp. } \\
\text { Argiope aemula } \\
\text { Argiope anasuja } \\
\text { Chorizopes sp. } \\
\text { Cyclosa hexatuberculata } \\
\text { Cyclosa moonduensis } \\
\text { Cyrtophora cicatrosa } \\
\text { Cyrtophora citricola } \\
\text { Cyrtophora sp. } \\
\text { Eriovixia excelsa } \\
\text { Gibbaranea bituberculata } \\
\text { Neoscona mukerjei }\end{array}$ \\
\hline Salticidae & $\begin{array}{l}13 . \\
14 . \\
15 . \\
16 .\end{array}$ & $\begin{array}{l}\text { Marpissa sp. } \\
\text { Plexippus paykulli } \\
\text { Plexippus sp. } \\
\text { Telamonia dimidiata }\end{array}$ \\
\hline Oxyopidae & $\begin{array}{l}17 . \\
18 . \\
19 .\end{array}$ & $\begin{array}{l}\text { Oxyopes chittrae } \\
\text { Oxyopes pankaji } \\
\text { Peucetia viridana }\end{array}$ \\
\hline Lycosidae & $\begin{array}{l}20 . \\
21 . \\
22 .\end{array}$ & $\begin{array}{l}\text { Hippasa madraspatana } \\
\text { Hippasa olivacea } \\
\text { Hippasa pisaurina }\end{array}$ \\
\hline Pholcidae & 23. & Crossopriza lyoni \\
\hline Thomisidae & 24. & Henriksenia hilaris \\
\hline Tetragnathidae & 25. & Leucauge celebesiana \\
\hline Eresidae & 26. & Stegodyphus sarasinorum \\
\hline Hersilidae & 27. & Hersilia savignyi \\
\hline
\end{tabular}

(04 species), Oxyopidae (03 species) and Lycosidae (03 species) and 01 species each from family Pholcidae, Thomisidae, Tetragnathidae, Eresidae and Hersilidae (Tables 2 \& 3).

Family Araneidae is most dominant family with 12 species. This family accounts for $44 \%$ of total species recorded in the present study. Araneidae is followed by Salticidae (15\% of total species), Lycosidae and Oxyopidae (each representing $11 \%$ of total species). Four families (Tetragnathidae, Eresidae, Hersilidae and Pholcidae) are each represented only by 01 species accounting for $3.57 \%$ of total species each. The images of 27 Spider Specimens are as given below.

\section{Discussion}

The results obtained show the dominance of spiders from family Araneidae (44\% of the total species) followed by families Salticidae (15\%), Oxyopidae and Lycosidae ( $11 \%$ each) and $03 \%$ of the species 

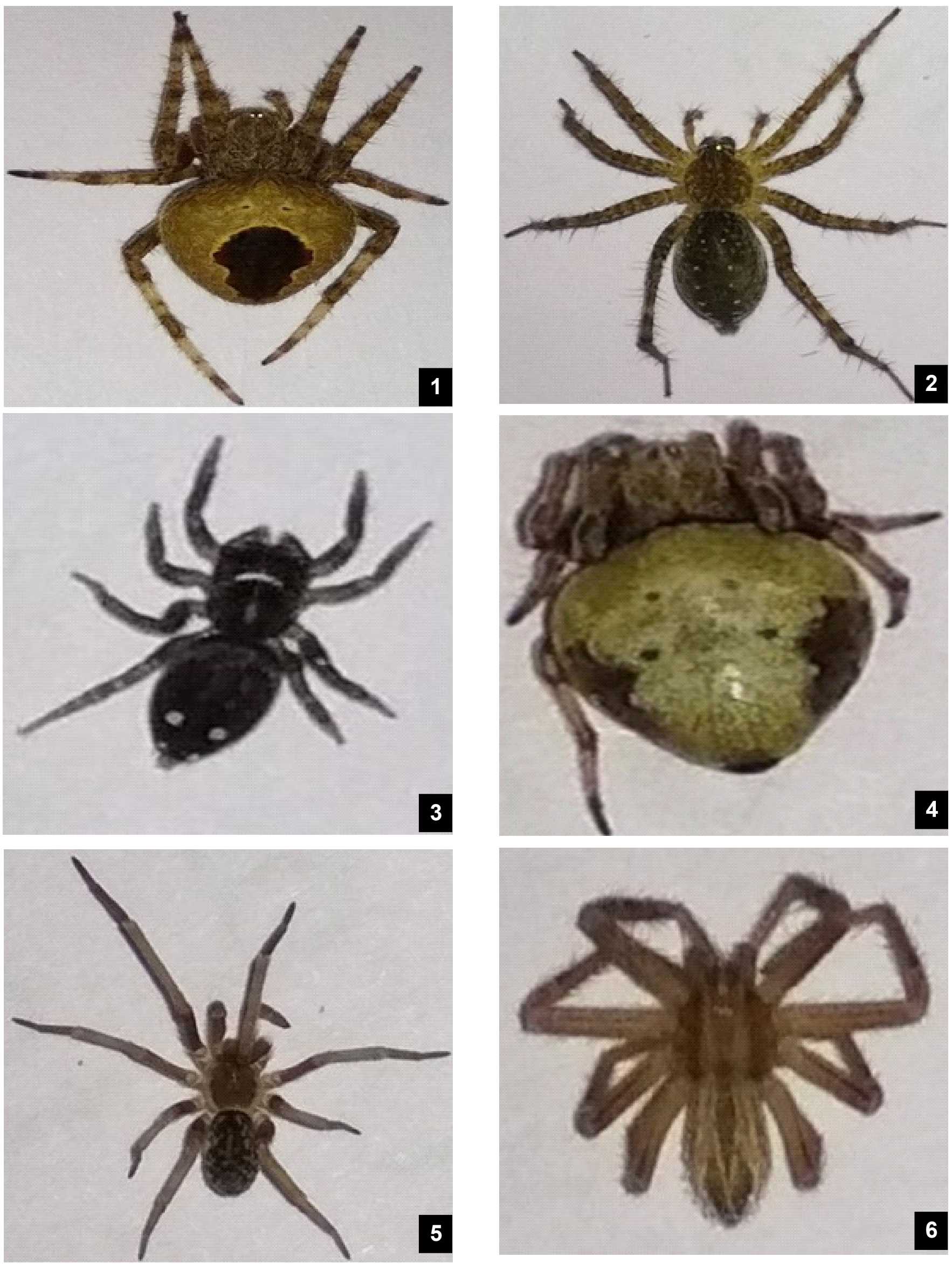

Figs : 1. Araneus sp., 2. Argiope aemula, 3. Argiope anasuja, 4. Chorizopes sp., 5. Cyclosa hexatuberculata, 6. Cyclosa moonduensis 

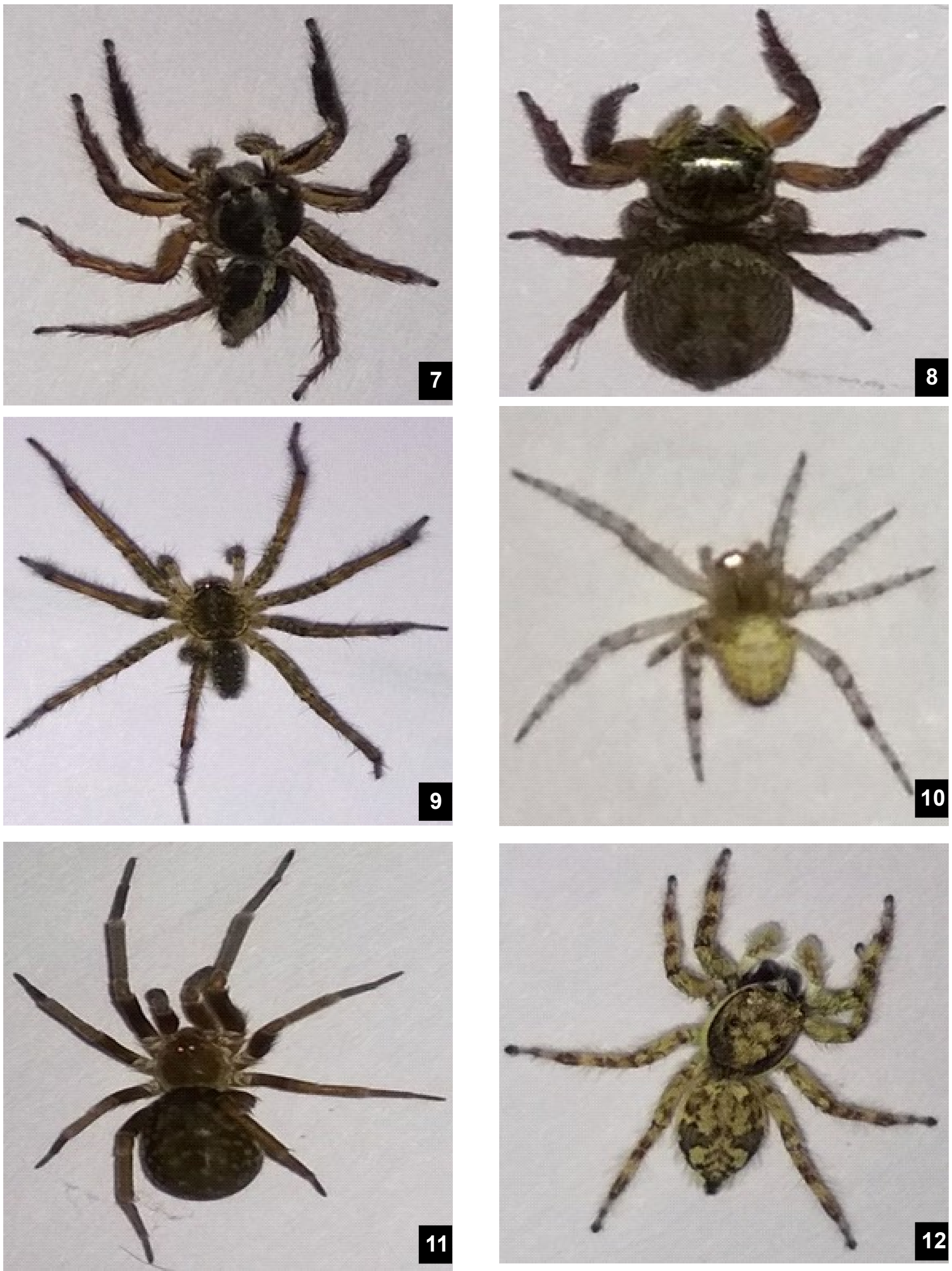

Figs. : 7. Cyrtophora cicatrosa 8. Cyrtophora citricola, 9. Cyrtophora sp. 10. Eriovixia excelsa, 11. Gibbaranea bituberculata, 12. Neoscona mukerjei 

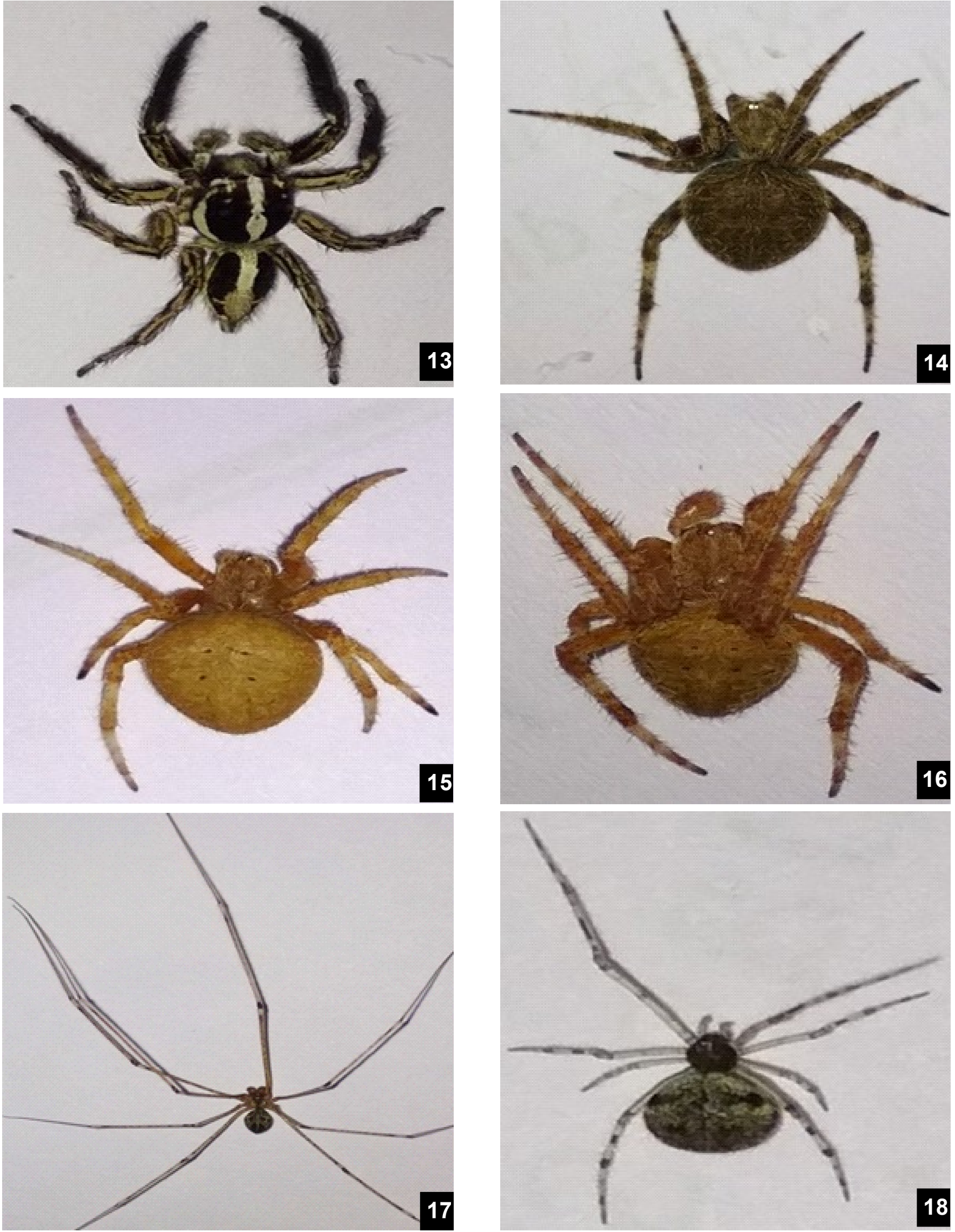

Figs. : 13. Marpissa sp., 14. Plexippus paykulli, 15. Plexippus sp., 16. Telamonia dimidiata, 17. Oxyopes chittrae, 18.0xyopes pankaji 

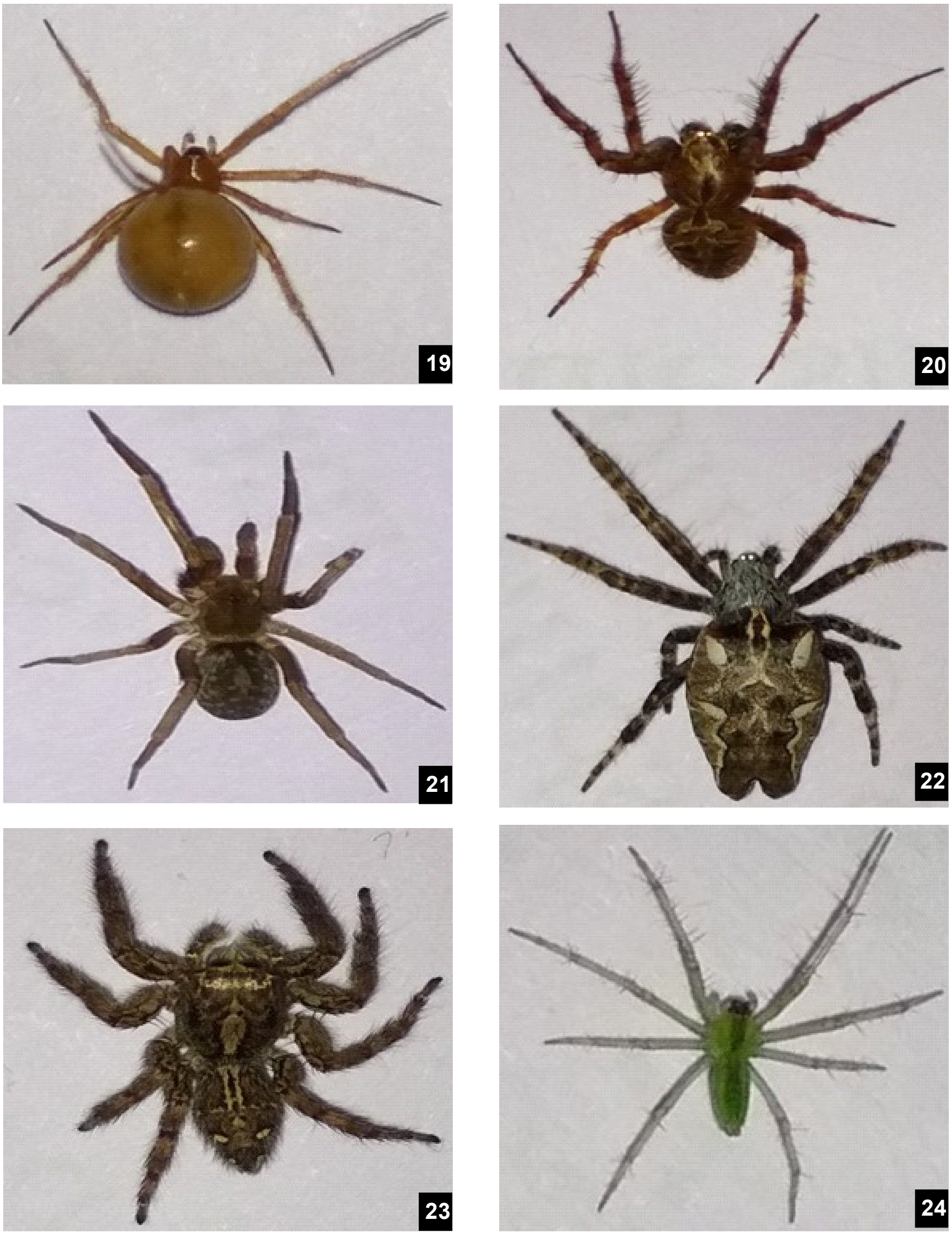

Figs. : 19.Peucetia viridana, 20. Hippasa madraspatana, 21. Hippasa olivacea, 22. Hippasa pisaurina, 23. Crossopriza lyoni, 24. Henriksenia hilaris 

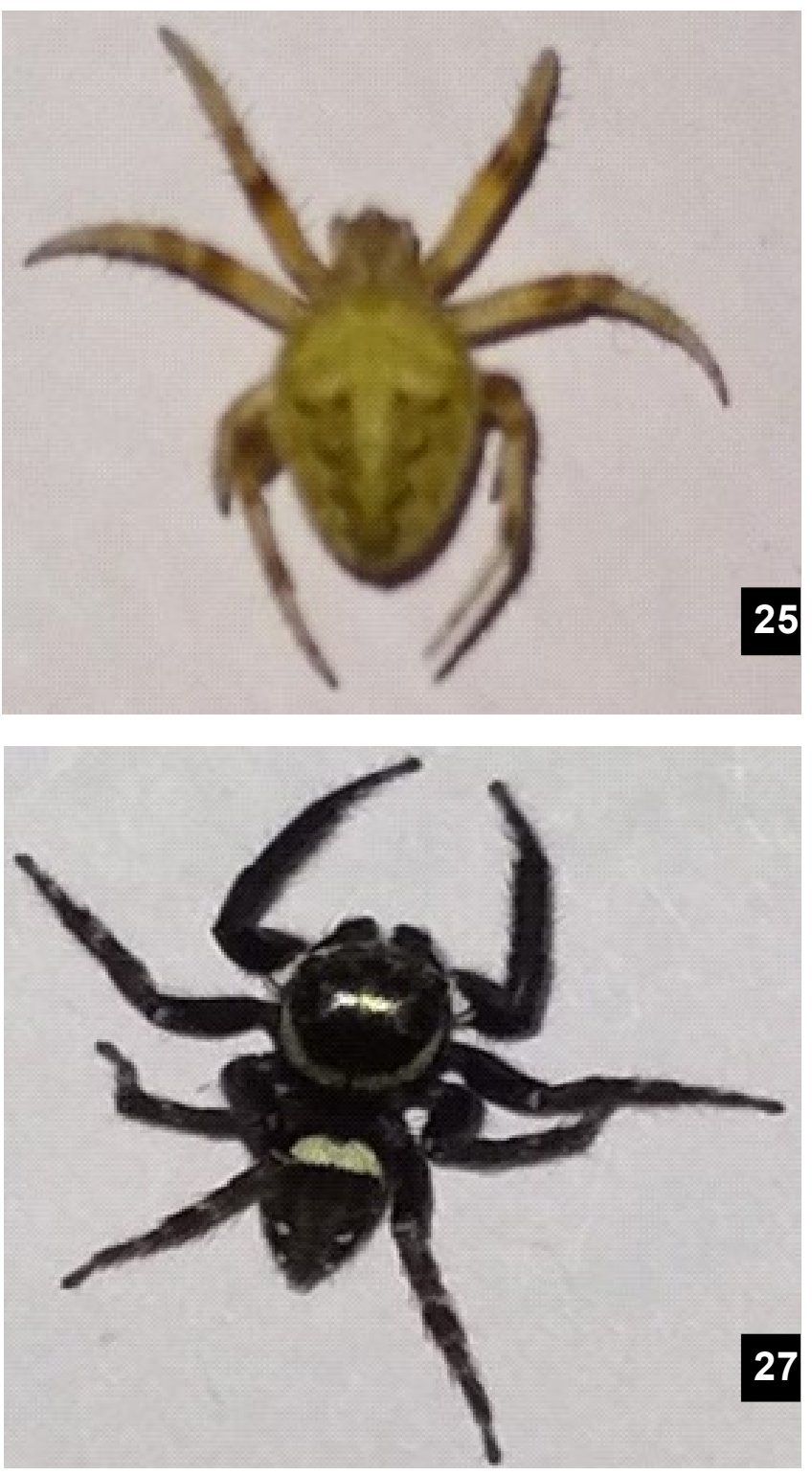

representation each from Pholcidae, Thomisidae, Tetragnathidae, Eresidae and Hersilidae. The results show that the ground-dwelling Spider families such as Salticidae and Lycosidae are quite common in the study area. Out of 252 genera of spiders from India 26,18 genera were recorded in the present study. Total 21 species mainly of hunting and web-making spiders in 19 genera of 13 families were reported from Karhandla ${ }^{7}$. Out of 60 families represented from Indian region ${ }^{14,15}, 09$ families were represented from Ahmednagar region. This means that $15 \%$ of the families were represented in the study. The high diversity of spiders in Ahmednagar can be attributed to high diversity of spider habitats (plants, farm areas, agricultural fields) in the area. Our results are quite similar to those obtained earlier ${ }^{33}$, wherein recorded 32 spider species from Pune area. The results obtained are in confirmity with the earlier studies $2,10,16,17,20,21,32$.

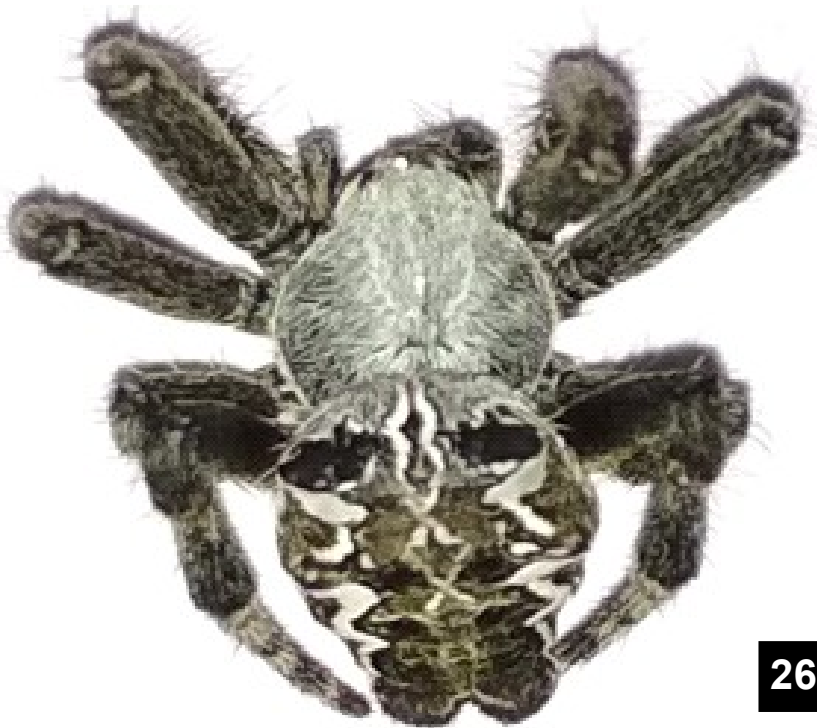

Figs. : 25. Leucauge celebesiana,

26. Stegodyphus sarasinorum, 27.Hersilia savignyi

TABLE- 3: Family Wise Number of Species

\begin{tabular}{l|l|c}
\hline Sr. No. & Family & Species \\
\hline 1 & Araneidae & 12 \\
\hline 2 & Pholcidae & 1 \\
\hline 3 & Lycosidae & 3 \\
\hline 4 & Hersilidae & 1 \\
\hline 5 & Oxyopidae & 3 \\
\hline 6 & Thomisidae & 1 \\
\hline 7 & Salticidae & 4 \\
\hline 9 & Tetragnathidae & 1 \\
\hline
\end{tabular}

\section{Conclusion}

The present study is a result of preliminary survey of spider fauna. However, further studies are essential to explore spider diversity and to find out more species of spiders from the Ahmednagar district. 


\section{References}

1. Adis J, Harvey MS. How many Arachnida and Myriapoda are there world-wide and in Amazonia? Stud. Neotrop. Fauna Environ. 2000 ; 35: 139-141.

2. Bawaskar K, Haldar R, Kosankar S. Fauna Diversity of CSIR-NEERI Campus, Nagpur, Maharashtra, India, Int. J. of Life Sci. 2018; 6 (2): 311-325.

3. Clks. Source, indigenous agricultural news unit on "Traditional Indian agricultural, (CIKS - Centre for Indian Knowledge System) India. 2002; 1-2.

4. Cohn J. Is it size that counts? Palp morphology, sperm storage and egg-hatching frequency in Nephila clavipes. J. Arachnol. 1990; 18: 59-71.

5. Coddington JA, Levi HW. Systematic and evolution of spiders (Araneae). Annu. Rev. Eco. Syst. 1991; 22:565592.

6. Foelix RF. Biology of spiders. 2nd ed. Oxford University Press, Oxford. 1996.

7. Gajbe PU. Record of Some Spiders (Arachnida: Araneae) from Karhandla in Nagpur District, Maharashtra, JNBR. 2016; 5(3): 133-138.

8. Gravely FH. Notes on Indian mygalomorph Spiders. I. - Records of Indian Museum. 1915; 11: 257-287.

9. Gravely FH. Notes on Indian mygalomorph spiders. II. - Records of Indian Museum. 1915; 37: 69-84.

10. Halarnkar MM, Pai IK. Distribution, Diversity and Ecology of Spider Species at two different Habitats, Int. Nat. Jou. of Env. Sci. and Natl. Resour. 2018; 8(5): 01-06.

11. Hansel M. Second hand silk. Natural History. 1993; 102: 40-46.

12. Hirst AS. On some new or little-known mygalomorph spiders from the Oriental Region and Australasia. Records of Indian Museum. 1909; 3: 383-390.

13. Johnston JM. The contribution of microarthropods to above ground food webs: A review and model of belowground transfer in a coniferous forest, American Midland Naturalist. 2000; 143: 226-238.

14. Jose SK, Sabestian PA. Occurance of Psechrus alticeps Pocock (Araneae:Psechridae) in Western Ghats, Kerala with a redescription and notes on its habit and habitat. Journal of the Bombay Natural History Society. 2001; 98: 304-306.

15. Jose SK, Sudhirkumar AV, Davis S, Sebastian PA. Preliminary studies on the spider fauna (Arachnida: Araneae) in Parambikulam wildlife sanctury Western Ghats, Kerala, India. J. Bombay Natral History Society. 2006; 102.

16. Jose AC, Sudhin PP, Prasad PM, Sreejith KA. Spider Diversity in Kavvayi River Basin, Kerala, Southern India, Current World Environment. 2018; 13(1): 100-112.

17. Lawania KK, Mathur P. Biodiversity and Habitat Preference of Spider Fauna in Eastern Región of Rajasthan and Catchment Area, Int. Jou. of Sci. Dev. and Res. (IJSDR). 2017; 2 (6): 475-484.

18. More S. Diversity of Spider fauna from Bamnoli region of Koyna wildlife Sanctury, Int. Jou. of Sci. and Res. (IJSR). 2013; 1690-1693.

19. More S. Diversity of Spiders from Zolambi Region of Chandoli National Park, IOSR Jou. of Pharmacy and Bio. Sci. (JPBS). 2015; 10 (2) Ver.1: 30-33.

20. Nalini BG, Ravindranatha BP. Spider Diversity in IISc, Bangalore, India, Indian Journal of Archaeology. 2012; 1(2): $50-58$.

21. Nerlekar AN, Warudkar AM, Gowande GG, Salve SS, RautA, Patankar SR, Nalavade SB. A review of the faunal diversity of the Fergusson College, Pune, India, Zoo's Print. 2016; XXXI, (10) : 04-25.

22. Pocock RI. Notes on the identity of some of the types of Mygalomorphae in the collection of British Museum. Annals and Magazine of Natural History, 1895; 16: 223-230. 
23. Pocock RI. Diagnoses of some new Indian Arachnida. Journal of Bombay Natural History Society. 1899; 12: 744753.

24. Pocock RI. Great Indian Spiders, The Genus Poecilotheria: its habits, history and species, Journal of Bombay Natural History Society. 1900; 13: 121-133.

25. Riechert SE, Bishop L. Prey control by an assemblage of generalist predators: Spiders in a garden test system. Ecology. 1990; 71:1441-1450.

26. Siliwal M, Molul S, Biswas BK. Indian Spiders (Arachnida: Araneae): Updated checklist 2005. Zoos' print Journal. 2005; 20 (10): 1999-2049.

27. Skerl KL. Spider Conservation in the United States. Endangered Species Updates. 1997; 14:11.

28. Smith AM. A new species of the arboreal theraphosid, genus Poecilotheria, from southern India with notes on its conservation status. Journal of British Tarantula Society. 2004; 19: 48-61.

29. Tikadar BK. Studies on some mygalomorph spiders of the families Ctenizidae and Theraphosidae from India, Journal of the Bombay Natural History Society. 1977; 74: 306-319.

30. Tikader BK, Biswas B. Spider fauna of Calcutta and vicinity: Part-I. Zoological survey of India, Controller of Publications, Delhi. Calcutta. 1981; 1-149.

31. Tikader BK. Handbook Indian Spiders (Anon. Ed.). Zool. Surv. India, Calcutta. 1987; 1-251.

32. Umarani S, Umamaheswari S. Diversity of Spiders fauna at different sites in Palani hills, Dindigul district, Tamilnadu, South India, Int. Jou. Of Adv. Biol. Res. 2013; 3(4): 535-539.

33. Wankhade, VW, Manwar, NA, Rupwate AA, Raut, NM. Diversity and abundance of spider fauna at different habitats of University of Pune, M. S. (India), Global advanced Research Jou. of Env. Sci. and Toxicol. 2012; 1(8): 203-210.

34. Wankhade VW, Manwar NA. Diversity and Guild structure of Spider fauna at Sawanga-Vithoba Lake (Malkhed Project) area in Pohara forest District Amravati, Maharashtra, India, International Journal of Zoology and Research (IJZR). 2013; 3(1): 07-16. 